\section{O caráter intertextual dos dêiticos de memória em memes do Facebook}

The intertextual character of memory deixis in Facebook memes

\section{Ana Cátia Silva de Lemos Colares (D) 9}

analemoscatia@gmail.com

Universidade Federal do Ceará - UFC

\section{Maria Margarete Fernandes de Sousa (D) (9) \\ margarete.ufc@gmail.com}

Universidade Federal do Ceará - UFC

\section{Resumo}

Neste artigo, temos como objetivo de estudo analisar o traço intertextual expresso nos elementos dêiticos de memória, além das formas lexicais que podem assumir essa função dêitica. A fim de evidenciar o caráter intertextual dos dêiticos de memória no gênero textual meme, discorremos sobre a noção de campo dêitico apresentada por Bühler ([1934] 1982), nas pesquisas sobre referenciação de Apothéloz (1995, 2003), Cavalcante (2000, 2011, 2013), também nos estudos sobre dêixis de Fillmore ([1984] 1997) e Lyons (1997). Para isso, analisamos memes, retirados da página Nazaré Orientadora, do Facebook, cujos resultados indicam que os dêiticos de memória podem assumir formas lexicais diferentes daquelas demonstradas por Apothéloz (1995), como o uso de advérbios, além de admitir traços intertextuais em sua função. Concluímos, dessa forma, que os dêiticos de memória podem ser admitidos por formas lexicais diferentes dos pronomes demonstrativos, além de assumirem um caráter intertextual como marca de sua função referencial.

\section{Palavras-chave}

Referenciação; Dêixis de Memória; Intertextualidade.

\section{Abstract}

In this article, we aim to analyze the intertextual trait expressed in the deictic elements of memory, in addition to the lexical forms that may assume this deitic function. In order to highlight the intertextual character of memory deitics in the meme textual genre, we will discuss the notion of deitic field presented by Bühler ([1934]1982), in the referencing researches of Apothéloz (1995, 2003), Cavalcante (2000, 2011, 2013), also in the studies on deixis of Fillmore (1982) and Lyons (1995). For this, we analyzed memes taken from the page Nazaré Orientadora, from Facebook, whose results indicate that the memory deitics can take lexical forms different from those demonstrated by Apothéloz (1995), as the use of adverbs, in addition to admitting intertextual traits in its function. We conclude, therefore, that memory deitics can be added by lexical forms different from demonstrative pronouns, besides assuming an intertextual character as a mark of their referential function. Keywords

Referentiality; Memory Deixis; Intertextuality.

\section{Linguagẹm Foco}

Revista do Programa de Pós-Graduação em Linguística Aplicada da UECE

FLUXO DA SUBMISSÃO

Submissão do trabalho: $23 / 10 / 2020$ Aprovação do trabalho: 04/12/2020 Publicação do trabalho: 22/01/2021

\section{COMO CITAR}

COLARES, Ana Cátia Silva de Lemos; SOUSA, Maria Margarete Fernandes de. O caráter intertextual dos dêiticos de memória em memes do Facebook. Revista Linguagem em Foco,v.12,n.3,2020.p.383-404. Disponível em: https://revistas.uece.br/index.php/linguagememfoco/article/ view/4251. 


\section{Introdução}

Investigações que se dediquem ao fenômeno dêitico são necessárias para uma melhor compreensão das práticas de linguagem em que esses elementos estão inseridos, uma vez que, ainda hoje, parece haver um apego na compreensão desses elementos relacionado, muitas vezes, a sua forma, em detrimento de sua função.

Entendemos que é preciso compreender esse fenômeno como uma prática de linguagem não apenas caracterizada, atualmente, por uma forma pronominal, mas compreender as funções estabelecidas nos contextos de usos desses elementos. Dessa feita, defendemos que a dêixis de memória, assim como o fenômeno dêitico em si, deve ser encarado como uma ação de linguagem definida por um contexto em que se reconhecem os sujeitos inseridos, por isso, assumimos o ponto de vista sociocognitivo-discursivo da linguagem.

Para isso, é preciso esclarecer o próprio conceito de contexto, além de considerar os estudos sobre os critérios definidores da dêixis, objeto de pesquisa de muitos estudiosos, como Benveniste (1995) e Bühler ([1934]1982), que contribuíram para a definição e para a caracterização do espaço do campo mostrativo' do fenômeno.

Por isso, precisamos encarar a relação dos elementos dêiticos que está condicionada à situação da enunciação, uma forte característica desses elementos, bem como a relação desses marcadores referenciais, cujo objetivo é deslocar o campo da atenção para um referente, característica, inclusive, apontada por Bosh (1983 apud APOTHÉLOZ 2003, p.68) como uma das principais diferenças entre os processos referenciais da dêixis e da anáfora; enquanto esta mantém a atenção sobre um referente, aquela desloca o campo da atenção para um referente.

Dessa forma, a anáfora e a dêixis não são processos opostos, mas processos referenciais que se sobrepõem positivamente a favor da construção dos sentidos dos textos, como já admitiu Cavalcante (2013), exercendo funções diversas estabelecidas pela constituição total do texto. Nesse sentido, acreditamos que algumas dessas funções, nos dêiticos de memória, podem ser atribuídas ao caráter intertextual que esses elementos podem ter em contextos de uso.

Assim, diante da constante atualização de informações trocadas pelos

1 Bühler (1982) definiu campo mostrativo como o espaço da enunciação em que se dão as coordenadas que situam os participantes da enunciação. Para ele, o campo mostrativo se opõe ao campo simbólico que marca a ausência do fenômeno dêitico. 
falantes, sobretudo no contexto informatizado atual, a recuperação de informações, bem como sua introdução nos diálogos, é marcada pelo uso de dêiticos, o que torna esse processo referencial essencial para o sucesso das práticas interativas dos falantes.

Ocorre que, nesse contexto, os fenômenos dêiticos estão assumindo funções novas, fazendo emergir a necessidade de estudos contínuos sobre seus reflexos para os estudos da linguagem. Dessa forma, este trabalho pretende investigar algumas dessas alterações no processo de apreensão dos dêiticos de memória, especificamente, pois acreditamos ser este tipo de dêitico um exemplo das mudanças nos usos desses elementos.

Dessa feita, buscamos, neste artigo, analisar o traço intertextual que julgamos ter encontrado nos elementos dêiticos de memória, para o que discorremos sobre a noção de campo dêitico apresentada por Bülher (1982), que será fundamental para diferenciar os tipos de dêiticos, bem como as noções sobre referenciação de Apothéloz (1995, 2003), Beaugrande e Dressler (1981), Cavalcante (2013), além dos estudos sobre dêixis de Fillmore ([1984] 1997) e Lyons (1995). Além disso, valemo-nos dos trabalhos de Kristeva (1974), Genette (2006), Koch; Bentes e Cavalcante (2007) para a compreensão do conceito de intertextualidade

A fim de demonstrarmos essa relação da intertextualidade com os mecanismos dêiticos, buscamos exemplificar, mediante o gênero memes da internet, o modo como esse traço intertextual é recuperado nos processos de interação social, pois esse gênero é um exemplo das constantes interações sociais e marca um comportamento muito comum na sociedade atual: a prática de compartilhamento de pontos de vistas por um grupo comum.

A seguir, apresentamos as noções de referenciação e dêixis, bem como o conceito desses elementos e sua importância para a construção de sentidos dos textos. Em seguida, apresentamos as concepções de intertextualidade que embasam esta investigação; depois, relacionamos os dois processos discursivos em nossa análise de memes do Facebook e, por fim, apresentamos nossas últimas considerações sobre o tema debatido.

\section{A dêixis e a importância do campo dêitico e os dêiticos de memória}

A maneira como a língua é utilizada para fazer referência aos objetos do mundo percorre um caminho longo, no que diz respeito às maneiras de categorizar as relações construtoras dos textos. Os estudos em referenciação fazem 
menção à construção dos referentes que condicionam os eventos semânticos dos textos; por consequência disso, compreendemos que os significados são instaurados em processos de coprodução entre ouvinte e falante, ocasionando a realização da linguagem nas práticas discursivas.

Assim, hoje, acredita-se que é a nossa prática social que rege a construção referencial dos textos, conforme defende Cavalcante (2011, p.15): "[...] referentes são entidades que construímos mentalmente quando enunciamos um texto. São realidades abstratas, portanto imateriais". A partir dessa definição, defendemos, como posiciona-se Cavalcante (2011), também em consonância com Mondada e Dubois (1995) e Dubois (2003), que a construção dos referentes ocorre mediante um processo de interação, do qual emerge o discurso, local de intercâmbio de práticas intersubjetivas dos sujeitos da enunciação.

Assim, podemos reconhecer funções referenciais dêiticas em formas verbais, como no trecho: "Quando criança, era tagarela", em que a forma verbal destacada marca não apenas a pessoa do discurso, caracterizando um dêitico pessoal, como também atribui conotação temporal ao enunciado.

No entanto, é comum a associação das funções dêiticas com os pronomes, mormente quando se trata de elementos dêiticos de memória, sempre associados a pronomes demonstrativos, como descreve Apothéloz (1995, p. 35): [dêixis de memória é] "o sintagma nominal demonstrativo que pode referir in absentia, ou seja, ausência de qualquer antecedente de seu referente e sem que ele esteja presente na situação de enunciação"2. Porém, acreditamos ser essa uma prerrogativa de outras formas lexicais, não apenas dos demonstrativos, formas que funcionem determinadas pelo uso em processos interacionais e que reconheçam os aspectos sócio-históricos da linguagem.

Reconhecendo a função referencial como um estatuto linguístico constituído nos processos interacionais, admitimos que os elementos dêiticos de memória, como processos referenciais, são mecanismos utilizados nas práticas da linguagem, que podem assumir formas diferentes, a critério dos enunciadores e do processo de enunciação, conforme pontua Benveniste (1995, p.227): "É no uso da língua que um signo tem existência; o que não é usado não é signo; e fora do uso o signo não existe".

Para o autor, os processos referenciais são estabelecidos por relações marcadas no processo da enunciação que ocorrem na interação entre os falantes.

2 Um syntagme nominal démonstratif peut référer in absentia, c'est-à-dire em l'absence de toute désignation antecedente de son référent et sans que celui-ci soit presente dans la situation d'énonciation (APOTHÉLOZ, 1995, p.35, tradução nossa) 
Essa interação é marcada por um aparelho formal do qual fazem parte os sujeitos da enunciação (locutor e alocutário), a situação e os instrumentos, que podem ser específicos ou acessórios, os quais descrevem os recursos linguísticos utilizados pelos sujeitos para acessar a enunciação.

Ainda, segundo o autor, os instrumentos acessórios não estão dispostos no mundo; cabe ao locutor acessá-los, construí-los na enunciação, enquanto os instrumentos específicos são marcados pela permanência e são necessários para a efetivação da enunciação. Encaixam-se, nesta descrição, as categorias de pessoa (eu/tu), espaço (aqui) e tempo (agora), características dos dêiticos de mesmo nome, essenciais para a marcação do momento enunciativo, tendo em vista que, conforme Benveniste (1995, p.83), "Antes da enunciação, a língua não é senão possibilidade da língua".

É nesse ponto que Benveniste trata dos elementos dêiticos, que funcionam como instrumentos específicos para denotar os índices de pessoa, a relação de ostensão e as formas temporais (FLORES, 2013). No entanto, é fulcral destacar a função dos instrumentos acessórios na apropriação da enunciação, os quais efetivam a atribuição das formas específicas no momento do uso, uma vez que é na singularidade da situação enunciativa que é possível construir o sentido desses mecanismos referenciais.

Como denota Benveniste (1995), a ordenação do sistema linguístico obedece a normas sociais determinadas pela comunicação intersubjetiva, através das quais os falantes consideram os usos da língua em seus contextos sociais e culturais. Com isso, a realidade, inerente ao processo dialógico dos falantes, reflete uma troca de informações na qual a linguagem reproduz a realidade e pela qual os objetos do mundo são recriados (BENVENISTE, 1995, p.26). Nas palavras do autor: "a situação inerente ao exercício da linguagem [...] confere ao ato do discurso dupla função: para o locutor, representa a realidade; para o ouvinte, recria a realidade".

Defendemos que os dêiticos de memória colaboram para a construção do ato enunciativo com marcas que agregam valor acessório, sendo seu sentido construído unicamente para a compreensão precisa e imediata de um determinado ouvinte. Dessa forma, os dêiticos de memória não poderiam ser relacionados, apenas, ao uso de pronomes demonstrativos, conforme descreveu Apothéloz (1995, p. 35).

Tendo em vista que, como observamos em nossa análise a ser debatida na seção Discutindo a função dêitica de memória no gênero meme, algumas 
funções dos dêiticos de memória podem recuperar uma situação sociodiscursiva representada por instrumentos acessórios da enunciação, os quais descrevem, conforme Benveniste (1995), os recursos linguísticos utilizados para se compreender a enunciação, configurando uma modificação no uso de recursos pronominais para a indicação da função dêitica de memória. Para constatar essa mudança, faz-se necessário mencionar outras características desses mecanismos, como a ostensividade, mencionada por Benveniste (1995), e a noção de campo dêitico defendido por Bühler ([1934] 1982).

A noção de campo dêitico de Bühler ([1934] 1982) estabelece que a função dêitica é acessada mediante o estabelecimento de um campo que marca "o momento dêitico", que se opõe ao momento de ausência dessa função. O autor propõe, dessa forma, um campo em que a função dêitica é estabelecida e um campo em que ela se ausenta; este é chamado de campo simbólico, aquele de campo mostrativo.

O campo mostrativo, por sua vez, é composto por duas funções: a primeira, Bühler ([1934] 1982) chama de Ad oculos, marcadora de espaços, lugares e pessoas; a segunda, ele denomina de Am phantasma, que trata de um campo fictício, embora esteja situado em uma enunciação, mesmo que criada para determinado fim, como o literário, por exemplo.

É, entretanto, no campo mostrativo ad oculos que o autor ancora os pressupostos estabelecidos em seu trabalho, uma vez que, para ele, é neste espaço que ocorrem situações enunciativas reais, nas quais se estabelecem usos dêiticos situados na interação e em aspectos sócio-históricos. No entanto, como vimos, a enunciação é instaurada no ato discursivo estabelecido entre os falantes que podem recorrer a instrumentos acessórios para construir o referente compartiIhado na conversação, cujos instrumentos só ganham sentido no ato enunciativo e para os enunciadores em questão. Mesmo que eles não vivenciem o momento na prática, o ato referido é composto de sentido pela compreensão dos falantes.

De forma semelhante, dá-se a construção do campo dêitico am phantasma, pois, embora sejam situações cujo acesso se dá pelos elementos dêiticos, o interlocutor, que recupera esse referente, não necessariamente vivenciou tal situação, inferindo-a por uma situação discursiva que faz referência a uma situação real, embora, não necessariamente, tenha sido efetivamente vivenciada por quem recupera essa informação. Um exemplo dessa construção é quando indicamos um caminho a alguém que não sabe como chegar a determinado local. Nesse caso, buscamos construir um caminho a partir de referências conhecidas, mas ainda não vivenciadas por aquela pessoa que deseja conhecer o trajeto. As- 
sim, esse trajeto é construído virtualmente mediante uso de [muitas] estratégias dêiticas, estabelecidas pelo campo dêitico am phantasma.

Essa caracterização do campo dêitico am phantasma, vai ao encontro da definição de dêitico de memória apresentada por Apothéloz (1995) o qual atribui a marca in absentia a função estabelecida por esses elementos, mesmo que o autor tenha relacionado essa função a uma forma específica do léxico, os sintagmas demonstrativos, julgamos que essa característica é a marca singular desses elementos que pode ser encontrada em quaisquer formas linguísticas que venham a exercer essa função no ato enunciativo.

Apesar de a definição de Apothéloz (1995) ser bastante presa a determinada forma linguística admitida pela função dêitica, concordamos com sua definição, em parte, e resguardamos o ponto de vista de Cavalcante (2013), ao defender que a definição de um elemento dêitico só pode ocorrer mediante a incorporação e a identificação de um contexto sociocognitivo situado.

A autora, desde 2011, já identificara algo que denotasse o caráter dêitico para além do aspecto formal, uma vez que, em obra publicada nesse ano, definiu a função dos dêiticos demonstrativos da seguinte maneira: "É como se o demonstrativo fornecesse uma indicação linguística de que o campo dêitico saliente (porém não o único) para a localização do referente mencionado é o campo da memória, não apenas o da situação comunicativa, nem o do cotexto" (CAVALCANTE, 2011, p.113).

É possível recuperar, desse ponto de vista defendido pela autora, que uma das marcas que podem definir a função dêitica de memória reside na noção de campo dêitico que ela retoma de Bühler ([1934] 1982).

No entanto, apesar de indicar esse traço, não deixamos de considerar outras possibilidades para a recuperação dessa função, como o teor intertextual que identificamos no uso dos dêiticos de memória. Assim, ao reconhecer esse postulado, notamos que é possível localizar um traço intertextual em alguns dêiticos usados nos memes analisados. Dessa feita, para elencarmos melhor os motivos que nos levaram a estabelecer essa relação é necessário compreender o conceito de intertextualidade, suas origens e o que designa, informações que trazemos na próxima seção.

\section{Dêixis e intertextualidade}

A partir da década de 1960, a francesa Julia Kristeva cunhou o termo intertextualidade fundamentando-se no conceito de dialogismo bakhtiniano. Kristeva 
(1967) afirma que o discurso literário dialoga com outros textos e que, para ocorrer intertextualidade, é necessário que o leitor possa reconhecer a presença de outro texto ou de fragmentos produzidos anteriormente, que estabeleçam relação com o texto lido. Com isso, a autora estipulou uma relação de simetria e inclusão com o conceito de Bakhtin (2003, p. 272), o qual assevera que "cada enunciado é um elo na corrente complexamente organizada de outros enunciados".

Por sua vez, o termo dialogismo, em Bakhtin (2003), relaciona-se a discurso e diz respeito ao que ocorre nos processos dialógicos instaurados por um complexo de forças sociais que ocorrem nessas relações, condicionando à forma e às significações do que é dito. Desse modo, o discurso se constrói mediado pela interação e pela contribuição de cada interlocutor. Nesse sentido, deve passar pela consciência do outro para se constituir.

Por isso, Faraco (2003, p. 48) afirma: "o caráter dialógico é o fato unificador de todas as atividades linguageiras", reforçando o pensamento do autor russo, que admite que todas as relações socioculturais são intermediadas por discursos já proferidos de que cada interlocutor faz uso, assumindo, portanto, o estatuto da dialogicidade.

Dessa forma, o postulado dialógico de Bakhtin (2003) colabora para a definição da intertextualidade como um acúmulo de toda a experiência humana, desempenhando um papel altamente relevante no processo de formação da linguagem. Com isso, entendemos que, a intertextualidade é um princípio que contribui para a compreensão da linguagem, uma vez que toda relação cultural se constitui por meio de processos intertextuais.

Nesta pesquisa, nos embasamos na proposta de Koch, Bentes e Cavalcante (2007) para as quais a intertextualidade é um fenômeno localizado que colabora para a construção de sentido dos enunciados e marca a influência de outras porções enunciativas. Outra importante marca desse fenômeno é defendida por Nobre (2014), que admite ser a intertextualidade um processo planejado, ainda que o interlocutor não seja capaz de recuperar a relação intertextual, como as intertextualidades constituídas por alusão (NOBRE, 2014, p.24). Dessa maneira, a interpretação de fenômenos intertextuais para a compreensão dos sentidos dos textos ocorre de forma partilhada nos processos de interação comunicativa.

De maneira análoga, os processos de referenciação, como a dêixis de memória, dependem exclusivamente dessa interação social para constituírem significado, traço comum dos processos referenciais e da intertextualidade que nos levou a refletir sobre o caráter intertextual que alguns tipos de dêiticos podem 
revelar, mormente os dêiticos de memória, definidos por Apothéloz (1995) e tomados por Leal (2015) como elementos utilizados na "ausência de qualquer antecedente de seu referente e sem que ele esteja presente na situação de enunciação" ( LEAL, 2015, p.112).

Compreendemos, portanto, a intertextualidade como um processo em que todos os enunciados sofrem influência e, por isso, são constituídos por pedaços de enunciados de outros, sejam eles completos, sejam incompletos. Esse conceito influencia Genette (2006, p.16) para quem a intertextualidade ocorre "como presença efetiva de um texto em outro", ainda que, para o autor, o fenômeno seja interpretado como algo mais restrito e que não pode ser confundido com o conceito de dialogismo bakhtiniano.

Nesse ponto, concordamos com Cavalcante e Brito (2011) as quais defendem que:

[...]o dialogismo é constitutivo da linguagem, para alguns autores, como Kristeva (1974), a intertextualidade também o é. Mas este sentido de intertextualidade é tão elastecido que dispensaria a identificação de marcas intertextuais [...]. Esta é a razão principal para preferirmos operar com um conceito mais específico de intertextualidade, que, mesmo assim caracterizado, ainda não coincide, necessariamente, com a noção de heterogeneidade enunciativa (CAVALCANTE; BRITO, 2011, p. 261).

Esse pressuposto pode ser considerado herança da reformulação da perspectiva de Genette (2006), que Koch, Bentes e Cavalcante (2007) propuseram para os processos intertextuais em duas relações: stricto sensu e lato sensu. Essa relação, para as autoras, resguardaria os processos mais amplos que tomam como escopo os pressupostos dialógicos defendidos por Bakhtin. Já a intertextualidade de sentido restrito acontece quando um texto conhecido ou já produzido é inserido em um dado texto, estabelecendo, dessa forma, uma relação mais delimitada.

Esse tipo de relação admite quatro tipos de funções: temática, estilística, explícita e implícita, nas quais existem vários níveis de intertextualidade, respectivamente: temática (textos com um tema em comum), estilística (quando o autor imita estilos ou variedades linguísticas), explícita (quando ocorre a menção direta do autor no próprio texto: citação e referência), implícita (quando se usa, mas não se menciona a fonte: alusão e plágio). Ainda, existem a intertextualidade das semelhanças (com valor de captação) e das diferenças (com valor de subversão).

As próprias autoras chamam atenção para o fato de que essa divisão não significa que um enunciado ou texto se constitua apenas a partir de um deles, pois podem ser utilizados simultaneamente em um mesmo texto, assim como, 
em um mesmo enunciado, a incorporação de um único intertexto pode gerar diferentes tipos de intertextualidade, até mesmo mudanças de sentido, o que nos leva a concluir que a construção de sentido de um texto se dá mediante ativação e compartilhamento de conhecimento adquirido (CAVALCANTE, 2013, p.145) no desenvolvimento de processos intertextuai.

Assumindo a intertextualidade como um contínuo diálogo entre porções textual-discursivas, em consonância com a proposta de intertextualidade stricto sensu das autoras, admitimos que a intertextualidade acumula conhecimentos relevantes de maneira sitada, diante de textos já produzidos e desempenha um papel altamente relevante no processo de formação da (re)construção de sentido dos textos.

Como podemos notar, o autor deixa clara a necessidade de recuperação de um contexto construído socialmente para a compreensão da dêixis de memória. Assim, para que os interlocutores compreendam o sentido dessa forma, é necessária uma recuperação de um contexto estabelecido entre os participantes da cena enunciativa, sendo, portanto, obrigatório ativar a memória para o estabelecimento do sentido dessa forma, recuperando um contexto de experiência humana, tal qual se estabelece nos processos intertextuais.

A título de ilustração, apresentamos um exemplo de dêixis de memória utilizada como recurso referencial da canção Sei, de Nando Reis:

\footnotetext{
Sabe quando a gente tem vontade de contar

A novidade de uma pessoa

Quando o tempo passa rápido

Quando você está ao lado dessa pessoa

Quando dá vontade de ficar nos braços dela

E nunca mais sair

Sabe, quando a felicidade invade

Quando pensa na imagem da pessoa

Quando lembra que seus lábios encontraram

Outros lábios de uma pessoa

E o beijo esperado ainda está molhado

E guardado ali

Em sua boca

Que se abre e sorri feliz

Quando fala o nome daquela pessoa

Quando quer beijar de novo, muito

Os lábios desejados da sua pessoa

Quando quer que acabe logo a viagem

Que levou ela pra longe daqui

Sabe, quando passa a nuvem em brasa

Abre o corpo, o sopro do ar que traz essa pessoa

Quando quer ali deitar, se alimentar

E entregar seu corpo pra pessoa

Quando pensa porque não disse a verdade
} 
É que eu queria que ela estivesse aqui

Sabe, quando a felicidade invade

Quando pensa na imagem da pessoa

Quando lembra que seus lábios encontraram

Outros lábios de uma pessoa

E o beijo esperado ainda está molhado

E guardado ali

Em sua boca

Que se abre e sorri feliz

Quando fala o nome daquela pessoa

Quando quer beijar de novo, muito

Os lábios desejados da sua pessoa

Quando pensa porque não disse a verdade

É que eu queria que ela estivesse aqui

Eu sei

Fonte: https://www.letras.mus.br/nando-reis/1981984/, acessado em: 13/06/2019.

Nessa canção, o pronome demonstrativo aquela, na expressão "aquela pessoa", ativa uma lembrança específica e faz cada enunciatário retomar uma memória única cuja recordação é estabelecida devido a um processo referencial instaurado em toda canção, mediante uso de elementos referenciais dêiticos pessoais (você), temporais (quando) e espaciais (ali), além dos dêiticos de memória (daquela pessoa), levando o ouvinte a ativar uma recordação íntima e especial vivida. Isso é possível, mediante o uso do campo dêitico am phantasma ativado pela presença dos dêiticos de memória na letra da canção.

Toda letra da canção é construída por imagens que vão se ativando na memória do ouvinte e esse movimento enunciativo ocorre não apenas com uso de formas dêiticas de memória como Apothéloz (1995) sugere: sintagma nominal demonstrativo. Outros elementos dêiticos (destacados pelas autoras) são utilizados no intuito principal da canção: fazer o enunciatário recordar momentos com alguém especial.

Retomamos algumas passagens da letra para demonstrar como o uso de outras formas lexicais colabora para a construção desse sentido memorial: "[...] e o beijo esperado ainda está molhado e guardado ali, em sua boca [...]", nesse trecho o advérbio de lugar (ali) é utilizado para levar o enunciador a relembrar da boca de sua (seu) amada (o), cada enunciador será levado a uma referência de memória particular. Em outro trecho, o mesmo advérbio colabora na construção de uma referência que leva o enunciador a relembrar um lugar especial, cuja recordação será própria de cada enunciador ("Quando quer ali deitar, se alimentar e entregar seu corpo pra pessoa"), além disso, no sintagma "pra pessoa", encontramos outra referência dêitica memorial fora do padrão de sintagma nominal 
demonstrativo, tendo em vista que a pessoa é retomada no texto in absentia, como denota Apothéloz (1995).

Isso é relevante, nesta pesquisa, pois corrobora com nossa hipótese de que a função dêitica de memória, especificamente, não está ancorada em uma forma lexical única (sintagmas nominais demonstrativos), mas pode ser expressa por formas diversas do léxico; na canção, isso fica claro com a utilização do recurso repetitivo da palavra pessoa, conforme a elaboração da construção de sentido dos textos.

Dessa forma, essa ativação da memória é algo que pode ocorrer com a dêixis de memória sem necessariamente ser acionada por uma forma de sintagma pronominal. Ademais, essas formas auxiliam na ativação do fenômeno da intertextualidade, que pode ser utilizado para impulsionar o sentido desse tipo de dêixis, fato que colabora para que a forma pronominal não seja o único pré-requisito para o estabelecimento desse tipo de dêixis, abrindo espaço para a compreensão das relações dêiticas não apenas através da identificação de formas linguísticas, mas, sobretudo, pelo reconhecimento da função dêitica que quaisquer formas do léxico podem assumir, de acordo com o contexto.

Isso posto, julgamos ter elencado arcabouço teórico minimamente eficaz para a explanação de nossa análise com o fito de discorrer sobre o caráter intertextual dos dêiticos de memória em memes.

\section{Discutindo a função dêitica de memória no gênero meme}

A emersão de novos gêneros discursivos está estritamente relacionada às esferas de atividades humanas nas quais determinada comunidade discursiva interage e estabelece uma modalidade textual à proporção que fornece propósitos comunicativos variados de acordo com as condições de produção e o estilo. Nesse contexto, ocorre o advento do que hoje denominamos como "meme", caracterizado pelo compartilhamento constante por um grande número de pessoas na internet.

Dessa forma, meme pode ser definido por tudo que é copiado, compartilhado e que se espalha continuamente entre os participantes de determinada comunidade discursiva. A origem desse gênero digital pode ser evidenciada no fragmento:

O termo meme aparece pela primeira vez no livro The selfish gene (O gene egoísta) de Richard Dawkins, publicado em 1976, em que o autor faz uma analogia entre 
os termos gene e meme, uma vez que "gene" é a possibilidade biológica da disseminação de características genéticas de um ser para o outro, enquanto "meme" é a propagação de uma ideia dentro de uma cultura, a partir de replicadores (LISBOA, 2015, p.32).

Os memes utilizados nesta pesquisa foram retirados da página do Facebook Nazaré Orientadora. Embasamos nossa escolha metodológica no fato de a página compartilhar situações comuns à rotina de estudantes e professores, utilizando funções dêiticas ancoradas em situações do universo dessas categorias sociais.

O gênero selecionado é um exemplo de como a construção dos sentidos dos textos está associada a relações sociodiscursivas e ancorada em situações enunciativas, pois, apesar de já muito estudado por pesquisadores da Linguística de Texto, é comum notarmos um novo estilo do gênero meme não apenas na rede social mencionada, mas também em outras, como Twitter e, mais recentemente, Instagram. Nossa opção metodológica pela rede Facebook deve-se, ainda, ao fato de ela ser uma ferramenta que oferece aos usuários a opção de criar páginas dedicadas a assuntos comuns a algumas comunidades, como estudantes e professores.

Além disso, em consonância com Araújo e Leffa (2016, p.62), "no Facebook, as possibilidades criadoras são ainda maiores, uma vez que esta rede social, ao contrário do Twitter, possibilita a mobilização de diferentes modos semióticos na constituição das postagens".

Acreditamos que esse traço colabora para a grande produção de memes pelos usuários dessa rede, somando-se à facilidade de formação de comunidades que congregam algum vínculo comum, como expomos a seguir. Por isso, julgamos pertinente avaliar as práticas de uso de elementos dêiticos nesse gênero, mormente pelo fato de sua constante evolução denotar características diferentes, a cada uso, dessa função referencial. Selecionamos para esta pesquisa dez memes retirados da página do Facebook Nazaré Orientadora da rede social, a fim de demonstrarmos o caráter intertextual presente na função dêitica de memória, em destaque nos memes selecionados.

Por falta de espaço para apresentarmos todos os dados analisados, elegemos apenas dois exemplares de nossa amostra, que representam o total, a fim de demonstrarmos nossas constatações. Os memes foram selecionados sob o critério de conter algum elemento com função dêitica de memória, além de apresentarem a figura da personagem citada, pois, embora a página leve o nome dessa 
personagem, nem todos os memes compartilhados contêm a imagem dela.

A página, Nazaré Orientadora, reúne usuários de perfil acadêmico e é destinada a estudantes, cujos organizadores satirizam e ironizam situações comuns à vida de alunos da graduação e da pós-graduação. O nome da página já retoma esse universo, indicado pelo termo orientadora, figura característica do meio acadêmico e que é representada por uma personagem, Nazaré, (interpretada pela atriz Renata Sorrah) que ganhou fama por suas atitudes maldosas em um folhetim televisivo de grande repercussão no contexto social brasileiro.

Notamos que, na página mencionada, há uma construção de estereótipos a partir da inferência que a comunidade virtual constrói entre o relacionamento aluno-orientador, uma vez que usuários e seguidores da página atribuem ao sujeito orientador uma postura de rigidez e inflexibilidade, assumida pelo posicionamento encontrado na interpretação da vilã que intitula a página do Facebook, enquanto o sujeito aluno é construído a partir de uma representação de submissão.

Assim, os memes produzidos pela página citada estão situados nas práticas de linguagem estabelecidas nessa relação textual-discursiva que visa recuperar a postura vilanesca da personagem Nazaré e, a partir dela, (re)construir o sentido dos textos produzindo novas informações, a fim de se estabelecer o traço sarcástico/irônico do gênero produzido pela página. Observamos, a seguir, dois memes analisados que representam nossas constatações.

Figura 1 - Dêixis e sintagma adverbial

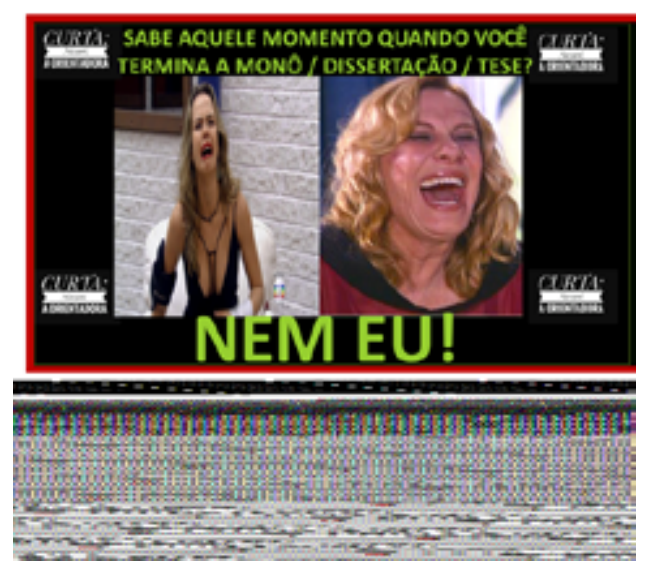

Fonte: Facebook/NazaréOrientadora. Acessado em: 10/11/2017.

O texto em análise é composto por uma imagem na qual aparece a per- 
sonagem Nazaré, feliz, ao lado de outros colegas de trabalho, compartilhando o mesmo sentimento, que vem expresso pelo texto verbal do meme: "Como a sala dos professores fica quando a garrafa de café chega". Podemos notar que as linguagens verbal e não verbal do gênero levam o leitor a se reportar a uma situação de alegria e satisfação, "quando a garrafa de café chega", associada à imagem da vilã de pé aplaudindo. O advérbio quando colabora para recuperar uma situação enunciativa comum no ambiente de trabalho de professores, principalmente, a hora do intervalo, havendo, assim, uma relação metonímica, segundo a qual a hora do café corresponde à hora do intervalo.

A linguagem verbal em associação com a linguagem visual cria um campo dêitico am phantasma, conforme denota Bühler ([1934] 1982), que reporta o leitor a uma situação específica in absentia, conforme Apothéloz (1995), (a chegada de café no ambiente de trabalho), que ele reconhece por compartilhar interesses com o produtor do gênero; afinal a página é destinada a alunos de graduação e de pós-graduação que, muitas vezes, já lecionam.

Acreditamos que o campo am phantasma, conforme Bühler ([1934] 1982), dá suporte para a existência da função dêitica de memória, uma vez que esse campo trata de uma situação não realizada na prática, mas, ainda assim, possível de ser recuperada pelos enunciadores, mediante um costume no uso da linguagem estabelecida pela função dêitica de memória, pois o leitor é levado a uma "mostração real" da situação, criada em seu campo de memória, mesmo que só consiga acessá-la mediante a imaginação ou recuperação dessa situação por meio de suas recordações pessoais, o que só é possível quando o leitor se reporta a tal situação enunciativa, marcada pela relação intersubjetiva demonstrada por Benveniste (1976) com as práticas da linguagem. O texto verbal do meme apresenta uma oração adverbial e, por meio dela, podemos recuperar um episódio de satisfação comum a professores em ambientes de trabalho, qual seja: a chegada de café fresco em suas salas que, muitas vezes, representa o intervalo do trabalho.

Com isso, percebemos que a função do advérbio quando, nesse contexto, pode ser admitida em compreensão de uma função prospectiva, levando, por exemplo, alunos de graduação que não são professores, mas leitores da página, a imaginar a alegria de professores diante de uma ação tão corriqueira quanto à disponibilidade de café no ambiente de trabalho. Acreditamos que o uso do advérbio quando marca um campo dêitico am phantasma que aponta para uma situação futura, para além, que pode ser reconhecida mediante a construção de planos e sonhos com os quais o interlocutor se identifica no contexto.

Nesse ponto, recordamos o postulado de Nobre (2014), que defende a 
existência de intertextualidade ainda que o interlocutor não a identifique; com isso, defendemos o traço intertextual que os dêiticos de memória possuem na construção de sentidos dos textos.

Além disso, o uso do advérbio quando pode também acionar uma recordação em leitores que são professores e compartilham de tamanha alegria diante da chegada de café em suas salas. Nesse caso, o vocábulo ativa uma memória compartilhada, impulsionando uma ação retrospectiva. Nesse ponto, usamos o termo para significar a presença do campo dêitico am phantasma, marcando a recuperação de fatos já ocorridos e retomados pela memória do enunciador que localiza essa situação vivenciada, ou pelo menos conhecida, em sua memória e, nesse caso, defendemos que haja, na função dêitica de memória em construção, traços de intertextualidade, que recuperam o aspecto textual-discursivo ativado pelo uso da linguagem verbal e não-verbal, pois, como vemos no meme, a alegria dos participantes deve refletir a alegria dos professores, a qual é reforçada pela frase "quando a garrafa de café chega", que colabora na recuperação da lembrança desse momento.

Tanto na situação retrospectiva quanto na prospectiva, notamos um reconhecimento do leitor da situação enunciativa que, por ser recuperada, constrói o sentido do texto, cujo acesso se dá também pelo forte caráter cognitivo na função dêitica de memória, conquanto, como é possível perceber pelo exemplo analisado, se o leitor não articular o traço recuperado em sua cognição com a situação discursiva estabelecida nas relações que permeiam os sujeitos desse gênero, este pode interferir na (re)construção do significado humorístico que caracteriza o meme.

Dessa forma, a função dêitica de memória é construída em um campo dêitico que alude às indicações dos enunciadores do gênero, permitindo o surgimento de um espaço de interação, considerando a linguagem realizada em sua plenitude na intersubjetividade do discurso. Além disso, no meme analisado, podemos perceber que o uso das formas Quando e Como colabora na marcação espaço-temporal que constrói a memória dos interlocutores, ativando recordações próprias de cada enunciado, instaurando um campo dêitico próprio das formas de memória.

É essa interação que permite ao leitor recuperar, em sua memória, a partir de uma forma linguística sociocognitiva contextualizada, uma situação vivida ou reconhecida por uma experiência compartilhada, pois essa função leva o leitor a construir um campo dêitico fora de seu espaço enunciativo atual, reportando ao 
que Bühler ([1934] 1982) denomina de campo mostrativo am phantasma:

Se o psicólogo se depara com quaisquer funções no campo da chamada retenção imediata, ele então busca funções análogas no campo da retenção, não imediatamente, mas mediadas, isto é, no campo das memórias maduras e da fantasia construtiva³ (BÜHLER, [1934] 1982, p.15, tradução nossa).

Além disso, notamos que o acesso a esse campo mostrativo ocorre também graças ao caráter intertextual que acreditamos possuir a função dêitica de memória, pois, ao enunciar "Quando a garrafa de café chega" e associar esse advérbio locativo a uma situação específica do ambiente de trabalho de professores, é possível associar uma experiência reconhecida como uma prática comum pelo leitor, configurando uma recuperação ampla dessa situação, o que pode demonstrar o traço intertextual desse tipo de função dêitica.

É possível, ainda em pesquisas posteriores, relacionar esse traço com a própria configuração do gênero, que, como demonstramos, é essencialmente intertextual, pois a associação da função dêitica ao caráter interssemiótico desse gênero contribui para o advento do traço intertextual da função dêitica, uma vez que a leitura do texto verbal não poderia alcançar significado sem a leitura da imagem que compreende o texto não-verbal.

Dado que, mesmo em situações prototípicas do dêitico de memória, como no uso de demonstrativos, apontado por Apothéloz (1995), só podemos acessar o referente dessa forma, caso sejamos reportados a uma informação anterior, que acessamos devido ao caráter intertextual dessa função. Como podemos notar pelo exemplo a seguir:

Figura 2 - Dêixis e sintagma pronominal

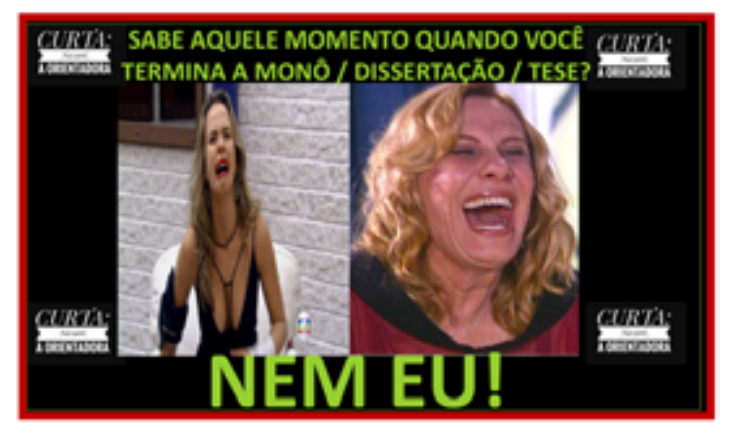

Fonte: Facebook/NazaréOrientadora. Acessado em: 10/11/2017.

Neste meme, a construção do sentido humorístico representativo da página é acessada, justamente, pela falta de recuperação do campo dêitico indiciado pelo uso do demonstrativo aquele, pois o uso do pronome demonstrativo 
aquele enseja apontar para uma coordenada espaço-temporal dêitica, construída e reconhecida pelos participantes de um enunciado. No uso em questão, o demonstrativo aponta para uma situação inexistente, ou melhor, para uma situação em que os interlocutores reconhecem existir, porém, nunca vivenciaram. Exatamente pela não-vivência desse momento e pelo reconhecimento de sua existência é que o sentido humorístico, com pitadas de ironia, é construído.

Para nós, isso é mais uma prova que aponta para o traço intertextual da função dêitica, que, como apresentamos, não pode ser classificada apenas pelo uso de elementos essencialmete gramaticais, como defende Apothéloz (1995). No caso, os interlocutores conseguem recuperar um momento textual-discursivo, ainda que não vivido por si, para alcançar o sentido do texto que é ratificado pelas imagens da personagem orientadora (vilã) Nazaré rindo da falta de vivência do término de um trabalho acadêmico ao lado da imagem de uma personagem da mídia mais jovem (representando um orientando), aos prantos, quando recupera a informação de que não sabe qual a sensação de finalizar seu trabalho.

É interessante notar que o uso do pronome demonstrativo neste exemplo torna-se salutar, no que se refere à ausência de contexto vivenciado recuperado, a fim de construir o sentido irônico do gênero, uma vez que, conforme Apothéloz (1995), esse tipo de sintagma está vinculado à dêixis de memória, no entanto, como podemos notar no exemplo da Figura 2, a forma gramatical não recupera um contexto vivido, mas uma situação construída de forma ficticiamente.

É justamente pela ausência de algo para se recordar que o sentido cômico do texto se constrói; mesmo assim, essa ausência é compartilhada pelo público alvo da página (estudantes de graduação e pós-graduação) que, por não saberem quais recordações o fim de um trabalho acadêmico traz, compartilham esse não sentimento.

No exemplo da figura 2, isso fica evidente, pois o campo dêitico criado pelo sintagma demonstrativo pode ser marcado pela ausência de reconhecimento do contexto, como denota Buhler ([1934] 1979), pois, mesmo que os enunciatários não reconheçam o momento de defesa do trabalho acadêmico como uma memória particular, a forma dêitica instaura um espaço que aponta para essa situação discursiva, mesmo que esse campo seja instaurado apenas ficticiamente.

Diante disso, o uso do elemento aquele, nesse contexto, não perde suas características dêiticas de memória, ainda que tal memória esteja mais assinalada por marcas de idealizações, sonhos, aspectos futuros, do que para lembranças, recordações, conforme denota a nomenclatura dos dêiticos de memória; neste 
caso particular, marcada por um traço prospectivo e não retrospectivo, como o estereótipo das formas pronominais usadas com essa função dêitica.

Com isso, esperamos contribuir na definição e conceituação dos dêiticos de memória, uma vez que percebemos alterações no uso dessa função apresentada por Apothéloz (1995), com um caráter essencialmente marcado por formas demonstrativas da língua. Como observamos, pelo uso dessa função no gênero meme da figura 1, o acesso ao repertório da memória do sujeito não está resguardado apenas pelo uso de demonstrativos, apesar de essas formas guardarem o uso mais prototípico dessa função, uma vez que formas adverbiais, como o quando, utilizado no exemplo citado, também podem colaborar para a recuperação de informações específicas incorporadas na memória do leitor, mas por outras formas que desencadeiam a relação. Além disso, o uso de outras formas lexicais na função de dêiticos de memória revela o traço intertextual que essa função referencial apresenta, relacionando-se com outros textos e mantendo uma relação dialógica no acionamento de sua função.

Na dêixis de memória, essa incorporação parece ainda mais evidente ao apontar, necessariamente, para situações enunciativas específicas e recuperadas pelo interlocutor por meio do fenômeno intertextual que recupera situações textual-discursivas próprias, contribuindo para a (re)significação do sentido dos textos e caracterizando, ainda mais, a construção de sentido mediante a interação dos processos enunciativos.

É importante salientar que, ao defender esse posicionamento, assumimos uma postura sociocognitivo-discursiva da linguagem. Dessa forma, resguardamos a postura de Cavalcante, Custódio Filho e Brito (2014, p.42) de que "a construção sociocognitivo-discursiva de objetos de discurso reveladores de versões da realidade [são] estabelecidos mediante processos de negociação". Assim, os significados dessa estratégia de referenciação são construídos na interação e não determinados por formas da língua.

Diante do exposto, passemos a nossas Considerações Finais.

\section{Considerações finais}

Neste trabalho, colaborar na conceituação e definição dos processos dêiticos de memória não como mecanismos presos a estruturas estanques, mas como processos construídos na enunciação.Para nós, esses elementos dêiticos apresentam características bem próprias dessa função, como o caráter intertex- 
tual que eles denotam e que esperamos ter demonstrado com o uso da função dêitica no gênero meme.

Além disso, como também contamos ter demonstrado, a função dêitica de memória admite um campo dêitico próprio, marcado pelas características am phantasma, atribuída por Buher (1982), estabelecendo marcas enunciativas que vão ao encontro do caráter intersubjetivo da linguagem, denotada por Benveniste (1995).

Dessa feita, associar a função dêitica a uma forma da língua significa reduzir os avanços da área. Por isso, faz-se, cada vez mais, necessário estabelecer as marcas de uso que parecem constantes dessa função.

Sabemos que essa discussão demanda, ainda, muitas contribuições, além de que a comprovação de um traço intertextual da função dêitica de memória deve envolver mais dados a fim de efetivar uma comprovação eficaz. No entanto, acreditamos que iniciar essa discussão e propor essa característica como marca da função dêitica de memória pode colaborar para o desenvolvimento e para a definição mais adequada desse processo referencial.

\section{Referências}

APOTHÉLOZ, D. Nominalisations, réferents clandestins et anaphores atypiques. In: BERRENDONNER, A. e M-J REICHLER-BEGUELIN (eds). 1995, p. 143-173.

;: REICHLER-BÉGUELIN, M.-J. Construction de la référence et stratégies de désignation.

In: In.: BERRENDONNER, A .e M-J. REICHLER-BÉGUELIN (eds.), 1995:227-271.

Papel e funcionamento da anáfora na dinâmica textual. In: CAVALCANTE, Mônica; RODRIGUES, Bernadete; CIULLA, Alena (Org.). Referenciação. São Paulo: Contexto, 2003, p. 53-84.

ARAÚJO, J; LEFFA, V. (org.). Redes sociais e ensino de línguas: o que temos de aprender? São Paulo: Parábola, 2016.

BAKHTIN, M. Estética da criação verbal. 4ed. São Paulo: Martins Fontes, [1953] 2003. BENVENISTE, E. Problemas de linguística geral I. 4 ed. Campinas: Pontes, 1995.

BÜHLER, K. (1934) The deitc field of language and deictic words. In: JARVELLA, R.J.; KLEIN, W.(eds). Speech, place and action: studies in dêixis and related topics. New York: John Wiley and Sons, 1982, p.9-30.

BEAUGRANDE, R. A., DRESSLER, W. U. Introduction to text linguistics. London: Longman, 1981. CAVALCANTE, M. A dêixis discursiva. Revista de Letras, Fortaleza, V. 1², N. 22, p. 47-55, Jan./Dez. 2000.

Referenciação: sobre coisas ditas e não ditas. Fortaleza: Edições UFC, 2011. 
BRITO, M. A. P. Intertextualidades, heterogeneidades e referenciação. Linha

d’Água, n. 24 (2), 2011, p. 259-276.

Os sentidos do texto. São Paulo: Contexto, 2013.

. Referentially. In: KONSTANZE, J; MILANO, $\mathrm{F}$ da. Manual of deixis in romance languages. Berlim/Boston: degruyter, 2015, p.493-510.

M; CUSTÓDIO FILHO, V; BRITO, P.A.M. Coerência, referenciação e ensino. São Paulo:

Cortez, 2014

FARACO, C.A. Linguagem e diálogo: as ideias do círculo de Bakhtin. São Paulo: parábola, 2003.

FILLMORE, C. J. Lectures on deixis. California: CSLI Publications Stanford, [1984]1997.

FLORES, V. N. Introdução à teoria enunciativa de Benveniste. São Paulo: parábola, 2013.

GENETTE, G. Palimpsestos: a literatura de segunda mão. Extratos traduzidos por Cibele Braga; Erika Viviane Costa Vieira; Luciene Guimarães; Maria Antônia Ramos Coutinho; Mariana Mendes Arruda; Mirian Vieira. Belo Horizonte: Viva Voz, 2006.

KOCK, I; BENTES, A; CAVALCANTE, M. Intertextualidade: diálogos possíveis. São Paulo: cortez, 2007.

KRISTEVA, J. Introdução à semanálise. Tradução de Lúcia Helena França Ferraz. São Paulo: Perspectiva, 1974.

LEAL, A. P. B. O processo referencial da dêixis: por uma proposta de recategorização. 2015. 293f.. Tese (Doutorado em Linguística) - Centro de Humanidades, Universidade Federal do Ceará, Fortaleza, 2015. Disponível em: http://www.repositorio.ufc.br/handle/riufc/12571. Acessado em: 18/05/2020.

LISBOA, V. L. Memes jurisprudenciais no Facebook do STJ: a constituição dialógica de um gênero verbo-visual. 2015. 107f.. Dissertação (mestrado em estudos da linguagem) - Universidade Federal de Goiás, Catalão, Goiás, 2015.

LYONS, J. Semántica linguística: uma introducción. Traducción de Santiago Alcoba. Barcelona: Paidós, 1997.

MONDADA, L; DUBOIS, D. Construção dos objetos de discurso e categorização: uma abordagem dos processos de referenciação. In.: CAVALCANTE, Mônica; RODRIGUES, Bernadete; CIULLA, Alena (Org.). Referenciação. São Paulo: Contexto, 2003.

NOBRE, K.C. Critérios classificatórios para processos intertextuais. 2014. 129f.. Tese (Doutorado em Linguística) - Centro de Humanidades, Universidade Federal do Ceará, Fortaleza, 2014. Disponível em: http://www.repositorio.ufc.br/handle/riufc/8243. Acessado em: 18/05/2020. 


\section{Sobre os autores}

Ana Cátia Silva de Lemos Colares - Doutoranda em Linguística pela Universidade Federal do Ceará, professora da rede privada de ensino, membro do grupo de pesquisa Gêneros Textuais: Perspectivas teóricas e Metodológicas - GETEME. Contato: analemoscatia@ gmail.com, Lattes: http://lattes.cnpq.br/3365667776366584, Orcid: https://orcid.org/00000002-2582-1994.

Maria Margarete Fernandes de Sousa - Doutora em Linguística pela Universidade Federal de Pernambuco, Professora associado, nível 4 do Departamento de Letras Vernáculas da Universidade Federal do Ceará, Coordenadora do Grupo de pesquisa Gêneros Textuais: Perspectivas teóricas e Metodológicas, vinculado ao Grupo de Pesquisa Estudos do Texto e do discurso - GETEME. Contato: margarete.ufc@gmail.com. Lattes: http://lattes.cnpq. br/5233227719780998. Orcid: https://orcid.org/0000-0002-4336-5486. 